\title{
EXPLORING FACTORS CAUSING LISTENING ANXIETY ON GENERATION Z STUDENTS
}

\author{
Neni Nurkhamidah \\ STKIP Media Nusantara Citra \\ neni.nurkhamdiah@stkipmnc.ac.id \\ neninurkhamidah@gmail.com
}

\begin{abstract}
Listening is a complex process because listeners do not only listen to the words, but they also interpret speakers' utterances. This complexity and difficulty triggers student's anxiety. Many researches find out that listening anxiety affect students' performance. Therefore, study on listening anxiety is crucial to be carried out. This study is conducted to find out the factors causing listening anxiety on generation $\mathrm{Z}$ students that raised with technology and have more opportunity to listen English from many sources than the previous generation. This is a qualitative study that is conducted in English Department of STKIP MNC by involving 20 participants from Basic Listening class. The finding shows that there are some factors causing students listening anxiety. The factor is categorized in two sources; students and technological factors. The internal factors trigger students listening anxiety are rate of speech, vocabulary and accent, and concentration. On the other hand, technological factor causing listening anxiety comes from the poor quality of audio sounds from speaker used in the class.
\end{abstract}

Key word: Listening, Listening Anxiety, Generation Z

\section{INTRODUCTION}

The importance of English language triggers foreign language educators to find new way to teach English to be more effectively and efficiently. There are many challenges faced by teacher and students in learning foreign and second language. However, due to the obstacles and challenges in learning English language, many EFL students experience anxiety. In psychological term, anxiety refers to a personality trait that influences the process of learning. The physical traits occur either learning in general or learning language (Atasheneh and Izadi 2012). Anxiety is also attested to be one of top rank among factors that affect language learning. It is an important affective filter which relates to success and failure in language learning (Fadillah ,2009; Kimura, 2011). As a language teacher, researcher receives complaints about 
student's anxiety especially during English listening class. Many learners blame anxiety as the cause of their poor performance because it obstructs their focus while listening process both in exercise and exam.

An early model of anxiety is proposed by Spielberger (1983) called as Trait-State Theory. As it is explained by Oteir \& Aziz (2017) that Trait-State Theory basically not discuss much about anxiety in learning language in detail, but it provides some ideas on anxiety which can be applied in language learning. The theory proposes that anxiety happens when learners think they are on the risky situation. This situation may come from either internal or external stimuli. A model of anxiety in language learning and how language anxiety is then developed by by Maclntyre and Gardner (1991). Three stages anxiety in the language learning are proposed; beginner, post-beginner and later phase. At the first phase, anxiety does not affect learners in language learning. At the next phase, the learners start to develop attitudes toward the second language learning context. Negative attitude and emotion will affect students' performance and achievement in language learning. At the last phase when negative attitude continues, then their anxiety level will get worse, and this situation will lead to poor performance in the language learning.

As listening is one important part in communication, people need to master listening skill for achieving effective communication. Many researchers assume that listening is difficult and complex skill. There are so many features in it. Listener not only receive the information from speakers, but they must process the meaning of the speakers' utterances. Comprehend people's utterance is not easy. Students in university find many problems in listening comprehension (Hamouda ,2013). This difficulty and complexity cause anxiety among second or foreign language learners (Graham, 2006).

Listening anxiety for second language learner is one of the important learner variables that affect success and failure in language learning.In spite of its' importance, Gonen (2009) clearly emphasizes listening comprehension anxiety as one of the most ignored type of anxiety. Moreover, he claimed that although many researchers realize the importance about specific studies of learning anxiety, yet the study of listening anxiety is still limit. The impacts of listening anxiety occur in two ways. Those types can be recognized as debilitating or inhibiting and enhancing facilitating or enhancing (Alpert and Haber ,1960 in Piniel and Csizér ,2013). Facilitating anxiety can act as a motivator that enhances students' performance. People who actually experience facilitating anxiety may not realize the presence of anxiety because this anxiety does not trigger tension. On the other hand, debilitating anxiety causes learners inhibit 
the language learning process. When students experience a debilitating anxiety, their performance is affected because it is destructive as well counterproductive to foreign language learning. The negative impact of debilitating anxiety relates to dropping motivation, negative attitudes and beliefs, that finally lead to language performance difficulties.

Agustina (2018) in her research on Indonesian students' anxiety level find out the anxiety level of Indonesian students is high. A study about the level of listening anxiety and the factors cause listening anxiety by Prastyowaty (2019) find out that students experience moderate level of listening anxiety and the high-level anxiety of student's anxiety is caused by students' background knowledge. The knowledge anxiety reflects on their worry about missing important information and they feel nervous when they found unfamiliar vocabulary. For some English learners, listening can be difficult due to many factors. Vogely (1998) pointed out factors contributing to listening anxiety in English as a second language. Those factors are the listening materials, the process of listening, teaching procedures and listeners' personal factors. The author tries to analyses the affecting factors from learners' aspect such as nature of the speech, level of difficulty, lack of clarity, lack of visual support, lack of repetition, spontaneous speech, fast speech, and unfamiliar accents/topics.

Pan (2016) divided the factors affecting listening anxiety in to four. The first is teacher factors. As we know that teacher is the person who are closely related to the teaching process. They must know students' condition in the class therefore they can provide appropriate material for learners. They have to know how to teach and how to encourage students in learning. The second factor is listening material and process. When the syntax is more complex, the speed is faster, and the pause is shorter the possibility of students experience anxiety will be more. The content, length, speed, vocabularies of listening material will influence the effect of hearing and anxiety. Other Factors affects listening anxiety based on Pan's suggestion is voice quality of recording, the condition of class too hot or too cold, too noisy, lacks oxygen, too small and cramped that also inspires anxiety in the listening classroom. Serraj (2015) proposed factors affecting listening anxiety into three group; individual factors, input factors and environmental factors. The individual factors include nerves and emotionality, using inappropriate strategies and lack of practice. Input factors including lack of time to process, lack of visual support, nature of speech and level of difficulty. The environmental factors, on the other hand, include instructors, peers and class environment. Kim (2000) explored the nature of listening input that cause of listening anxiety. Vocabularies, length of text, speed, pronunciation and intonation are the major source of students' anxiety in listening activities. Serraj (2015) find out major factors 
cause of listening anxiety in Sirian Students, those factors are individul, environmental and input factors. Prastiyowaty (2019) conclude that that students, teachers, input and other factors such as peer, room condition and environment and time limit are the factor lead students to listening anxiety.

As it is experienced by researcher as a lecturer in English Department students of STKIP Media Nusantara Citra, many students complain that listening makes them scared. It is necessary for teachers to understand the pressures felt by learners in the listening class because they have crucial role on students' performance. First year students take three credits Basic Listening class in the first semester. After conducting class, the teachers open sharing session with the students. Researcher find out that students show various symptoms of anxiety that occur in listening activities.

All students in listening class are Generation $\mathrm{Z}$ where they have been raised with technology. Born in 1996-2000, this generation mostly are autonomous and independent. They have ability to figure things out by themselves. They use sophisticated technology in daily life such as smartphones and laptops. Since they prefer to learn visually, they need a picture to retain information and increase understanding (Miranda:2015). A research shows that Generation Z prefers working independent than working with others, on the other hand they are suffering from Fear of Missing Out (FOMO) anxiety (Strong, 2016). Generation Z students are able to learn English from any resources by utilizing the technology. They can access various types English materials and develop their English skill. A huge number of free audios are easily to access with internet for developing their listening skill. They may learn from song, game, film and learning video as much as they want. Although the technology makes them familiar with English, they still feel scared in listening activities. The anxiety they face may be a bit different with what those faced by the previous generations. Through this study researcher try to find out the factors that cause listening anxiety in generation Z. This is first study that conducted in STKIP MNC. The results of this study are expected to be beneficial for English instructors to help students in dealing with their anxiety in listening class.

\section{METHOD}

Qualitative approach is applied to find out the factors cause listening anxiety. Qualitative is used to understand a certain problem or phenomena. In this study, the researcher wants to find out detailed understanding of the factors caused listening anxiety experienced by English Department of STKIP MNC. Since the purpose of qualitative approach is to explore people's 
thought, feelings, perceptions and beliefs, this approach is suitable to this study (Creswell, 2012). To collect the data from students, interview is employed. Interview is one of the most frequently use in qualitative research because respondent can use their own words to express particular situation and it is an effective tool to collect information of particular situation from respondent Creswell (2008). Since the interview was conducted face to face, the trustable relationship between researcher and respondent are built then it supports honest and credible answer from the respondents. (Basit,2010)

The participants of this research are 15 students in the Basic Listening Class of English Department students of STKIP MNC. Basic listening class is three credits required course must be taken by first semester students of STKIP MNC. The class is new for them since most of them never experienced listening class in the previous education. Semi-structured interview is applied with 15 questions to find detail about participants experience on the factors cause listening anxiety in Basic Listening class. Face to face interview takes 15 minutes maximum for each student. The interview was recorded, transcribed and checked with researchers' note taking. Thematic analysis steps followed by researcher before summing up the report are 1) familiarize the data 2) create the code 3) find out the theme 4) criticizing the theme 5) specify and name the theme 6) generate the report.

\section{FINDINGS AND DISCUSSION}

Before going to the main result of this study, researcher will underline some important information from interview with the respondents that will lead you to the answer of research question. It shows that all the respondents in this study have learnt English at least six years. But all students mentioned that in the previous education level, they only have small amount of listening activities because the focus of English learning in the previous degree is reading and writing. The respondents have either mobile phone or computer as the part of their life. They make use of internet connection to not only get information but also socialize with other people. This condition is related to what stated by Renfro (2012) that Generation Z are surrounded by internet environment and tech-savvy. The opportunity to listen to English in many ways is high because they can access English video and audio easily. Every day all participants listen English utterance either from YouTube, social media such as Instagram or Facebook, online game even English movie. When researcher asked 20 respondents the scale of anxiety in listening activities, 11 students indicate they experience high level anxiety the rest 9 students experience moderate 
level of anxiety. Related to the factors cause students listening anxiety in Basic Listening class, this following part will describe is as the main result of the study.

\subsection{Students' Internal Factors}

The majority sources of anxiety come from listening material that related to their English knowledge. Students comprehension ability have strong correlation with listening anxiety (Pan,2016). Studies have shown that the lower the learners' listening comprehension level, the higher the anxiety. Two aspects are included in listening comprehension are linguistic knowledge and the ability to predict the information. Linguistic knowledge contains grammar knowledge, lexical and syntax. Kaseem (2015) stated that there are many factors affected student's anxiety in listening comprehension such as lack of knowledge structure, vocabulary, unfamiliar topic, the speed of speaker and limited of time.

\subsubsection{The Speed Rate of Speech.}

Numerous scholars claimed that that one of the major aspects of listening anxiety is the rate of speech. The majority of participants mention that speed of speech causes the anxiety. Those students claimed that the speaker speaks to fast. Some of them also believe that the faster the speaker talk; the higher anxiety occurs. This result has the same point of view as what founded by Serraj (2015) and Ja'fr (2013) that the nature of speech is one of important factor causing listening anxiety. In listening activities students need to process utterance and information from speaker. For students experiencing listening anxiety, normal speed will seem too fast for them. They can's not catch the speaker's utterance or information from the speaker; therefore, they feel anxious.

\subsubsection{Unfamiliar Vocabulary}

The most fundamental in learning language is vocabulary. It is impossible for students to learn second or foreign language without knowing the words of the language. Vocabulary is needed in to learn four skill in English. The general perception is that learners who know more vocabulary will be more proficient in the various language skills. Hamouda (2013) state that the lack of vocabularies may hinder student in learning language. Six students in this study explain that unfamiliar vocabulary leads led to experience listening anxiety. As founded by Tahsildar and Shah (2014) and Agustiana (2018) that lack of vocabulary is a major obstacle for most students in learning listening. When students encounter unknown or unfamiliar vocabularies they will stop for a while to think about the meaning of the vocabulary. It may cause students to miss 
the next speech and finally they do not receive purposed information from the speech. Xuan, and Simanjuntak (2017) claimed that there is significant value between limitation vocabulary and listening anxiety. Therefore, the importance of having sufficient vocabularies can be neglected for the success of learning language and decrease the level of listening anxiety.

\subsubsection{Speakers' Accent.}

The are many English accents around the globe and those different can create room for misunderstandings. Understanding speakers' talk in certain accent that students are not exposed frequently is not easy. Students will be accustomed to the accent they listen to mostly. Unfamiliar accent may cause anxiety Agustiana (2018) and Gonen (2009). In Basic Listening class lecture use different accent/dialect of English speaker such as British, Indian, Japan, Arabian and some other dialect. In the interview students explain that some accents are unclear. They used to listen American accent from audio, video or movie from their gadget. They feel more comfortable to listen American English in listening Activities. That is why they feel anxious when they listen to English spoken in different accent.

\subsubsection{Lack of Concentration}

Researcher find out that one cause the listening anxiety is lack of concentration. Loosing focus happen especially when students have to listen to long conversation. Agustiana (2018) found out that concentration is the highest factor caused listening anxiety. Since in listening activity teacher only give once chance for student to listen the audio, they need continuous concentration. If students are unable to concentrate, it affects students' comprehension (Bloomfield, Wayland, Rhoades, Blodgett, Linck, \& Ross, 2011). Lack of concentration affected students' performance in listening activity. The smallest distraction disturbs students' listening comprehension. When the students are not fully concentrating in listening activity, their

performance will not be outstanding (Kutlu \& Aslanoğlu, 2009). Listening need high concentration because listening is a complex process, students need concentration to build mental representation of the utterance they listen to.

\subsection{Technological factors}

The development of technology triggers many educators utilize a wide number of Information and Communication Technology (ICT) that can help learners develop their listening skills because it facilitates the students to learn English language, provides huge number of 
learning materials and supports students a learning experiences (Khoirunnisa, 2019). Hardware, software, application and social media can be used in teaching and learning listening to achieve learning goals effectively. Strategy and policy in the use of technology is necessary to make learning with technology more effective and efficient. That is why teacher must pay attention on students and facility condition before implementing ICT in language learning

In spite of its benefit, technology also may bring anxiety in listening class. As it is found in this research that students are not accustomed to use audio speaker because the sound is unclear. The bad quality of the sound makes them anxious. They said that they prefer to use earphone as they usually do when they watch or listen English material from their gadget.

\section{CONCLUSIONS}

Listening skill is important skill to master in language learning. Due to its' complexity, in which students have to understands every word that speaker's say and interpret the meaning of speakers' utterances, many students overwhelmed anxiety in listening actives. This phenomenon also happens to students of STKIP MNC. The study shows that generation Z students of STKIP MNC college experience listening anxiety in Basic Listening Class.

There are some factors cause students anxiety in listening class. The factors are divided into two categorized, students' factors and technology factors. Students factors that trigger listening anxiety related to the nature of listening such as the rate of speech, students' knowledge such as vocabulary and accent, and concentration. On the other hand, technological factors come from the quality of sounds produced by the audio speaker.

As anxiety is claimed as one important factor that affects students' performance in EFL classroom, teachers have to pay attention to this situation. Furthermore, the finding provides information for teacher about student's anxiety in basic listening class. Hopefully more teachers conduct thorough study about listening anxiety to help students deal with the anxiety.

\section{REFERENCES}

Agustiana, V. (2018). Listening anxiety among Indonesian EFL students. Indonesian

Atasheneh, N \& Izadi, A. (2012). The Role of Teachers in Reducing/Increasing Listening Comprehension Test Anxiety: A Case of Iranian EFL Learners. English language Teaching. Canadian Center of Science and Education.

Basit, T. N. (2010). Conducting research in educational contexts. London: Continuum 
International Publishing Group.

Bloomfield, A., Wayland, S. C., Rhoades, E., Blodgett, A., Linck, J., \& Ross, S. (2011). What makes listening difficult?: Factors affecting second language listening comprehension. International Journal of Academic Research in Progressive Education and Development, 2(2). Continuum.

Creswell, J. W. (2008). Educational research: planning, conducting, and EFL Journal, 5(1), 1326. doi: 10.25134/ieflj.v5i1.

Fadillah Ridha. (2009). Anxiety and Students Achievement in English as a Foreign Language. Antasari Press Banjarmasin.

Gonen, M. (2009, July). The relationship between FL listening anxiety and FL listening strategies: The case of Turkish EFL learners. In Proceedings of the 5th WSEAS/IASME International conference on educational technologies (pp. 44-49).

Graham, S. (2006). Listening comprehension: The learners' perspective. System, 34, 165-182. http://dx.doi.org/10.1016/j.system.2005.11.001

Hamouda, A. (2013). An Investigation of Listening Comprehension Problems Encountered by Saudi Students in the EL Listening Classroom. International Journal of Academic Research in Progressive Education and Development, 2(2), 113-15.

Isnani, Khoirunnisa. (2019). A STUDY AMONG ENGLISH TEACHERS' PERCEPTIONS: INVESTIGATING THE ROLES OF ICT IN INDONESIAN EFL CLASSROOM. ETERNAL (English, Teaching, Learning, and Research Journal). 5. 247. 10.24252/Eternal.V52.2019.A6.

Ja'fr, S. (2013) Listening comprehension for first grade students of Department of English Language Arts at Al-Yarmouk University College. Diyala Journal, 58.

Kassem, Hassan. (2015). The Relationship between Listening Strategies Used by Egyptian EFL College Sophomores and Their Listening Comprehension and Self-Efficacy. English Language Teaching. 8. 10.5539/elt.v8n2p153.

Kim, J. H. (2000). Foreign language listening anxiety: A study of Korean students learning English.Unpublished doctoral dissertation. University of Texas, Austin. 
Kimura, H. (2011). A self-presentational perspective on foreign language listening anxiety. Retrieved from

Kutlu, Ö., \& Aslanoğlu, A. E. (2009). Factors affecting the listening skill. Procedia -Language Annals, 31, 67-80.

MacIntyre, P. D., \& R. C. Gardner. (1991). Language anxiety: Its relation to other anxieties and to processing in native and second languages. Language Learning, 41, 513-534.

Miranda.2015. Leading and Teaching The Next Generations: Gen $Y$ and Z. https://digitaluniversities.guideassociation.org/wpcontent/uploads/DU_2017_3_03_Miranda.pdf

Oteir, Ibrahim \& Abd Aziz, Noor Hashima. (2017). Exploring the Causes of Listening Comprehension Anxiety from EFL Saudi Learners' Perspectives: A Pilot Study. Advances in Language and Literary Studies. 8. 79. 10.7575/aiac.alls.v.8n.4p.79.

Pan, Y. (2016). Analysis of listening anxiety in EFL class. International Journal on Studies in English Language and Literature, 4 (6). Retrieved from https://www.arcjournals.org/pdfs/ijsell/v4-i6/2.pdf

Piniel, K., \& Csizér, K. (2013). L2 motivation, anxiety and self-efficacy: The interrelationship of individual variables in the secondary school context. Studies in second language learning and teaching, 3(4).

Prastiyowati, Santi. (2019). ANXIETY ON STUDENTS' LISTENING COMPREHENSION IN UNIVERSITY STUDENTS IN MALANG. A Journal of Culture English Language Teaching Literature \& Linguistics. 6. 65. 10.22219/CELTICUMM.Vol6.No1.65-77.

Renfro, A. (2012, December 5). Meet Generation Z. Getting Smart. Retrieved from http://gettingsmart.com/2012/12/meet-generation-z/

Serraj, S. 2015. Listening Anxiety in Iranian EFL learners. International Journal of Scientific and Research Publications, Volume 5, Issue 6

Spielberger, C. D., Gorsuch, R. L., Lushene, R., Vagg, P. R., \& Jacobs, G. A. (1983). Manual for the State-Trait Anxiety Inventory. Palo Alto, CA: Consulting Psychologists Press.

Strong, R. (2016). Social media, FOMO and the perfect storm for the QuarterLife Crisis. 
Retrieved at http://www.huffingtonpost.com/rebeccastrong/social-media-fomo-andthe_b_9880170.html

Tahsildar, Nasim \& Shah, Zailin. (2014). Investigating L2 students' listening anxiety: A survey at a Malaysian university. International Journal of Language Education and Applied Linguistics (IJLEAL).

Vogely, A. J. (1998). Listening comprehension anxiety: Students reported sourcesand solutions. Foreign Language Annals,31,67-80

Xuan, K., \& Simanjuntak, D. (2017). Studentsâ€тм Perspective of Factors Affecting Listening. Acuity: Journal of English Language Pedagogy, Literature and Culture, 2(1), 1-11. https://doi.org/10.35974/acuity.v2i1.584 